\title{
RENT-SEEKING PRACTICES IN THE HOUSING DEVELOPMENT APPROVAL PROCESS
}

\author{
Abdul-Rashid Abdul-Aziz ${ }^{1^{*}}$ and Suhaila Ali \\ ${ }^{1}$ School of Housing, Building and Planning, Universiti Sains Malaysia, Pulau \\ Pinang, MALAYSIA \\ ${ }^{2}$ Faculty of Architecture, Planning and Surveying, Universiti Teknologi MARA, \\ Seri Iskandar Campus, Perak, MALAYSIA \\ *Corresponding author: arashid@usm.my
}

Published online: 29 October 2021

To cite this article: Abdul-Rashid Abdul-Aziz and Suhaila Ali. 2021. Rent-seeking practices in the housing development approval process. Kajian Malaysia 39(2): 25-49. https://doi.org/10 $.21315 / \mathrm{km} 2021.39 .2 .2$

To link to this article: https://doi.org/10.21315/km2021.39.2.2

\begin{abstract}
The lengthy, uncertain and onerous planning approval process in various countries around the world has prompted frustrated housing developers to seek influence by paying off approving officials. A research was conducted in Malaysia to investigate in greater detail this rent-seeking phenomenon by asking six fundamental questions. Rich data were obtained by interviewing 22 housing developers and consultants who work for them. Developers engage in rent-seeking behaviours to overcome genuine and artificial hurdles when applying for development approval. All approving agencies, though not all their staff, reciprocate to such behaviours. The monetary value of the payoffs depend on the rank of the public actor and project features. The higher the office holder is, the larger is the expected pay-off. Big and complex development projects in urban centres have a higher pay-off tag. Low value items television sets and car repairs serve to support normal lifestyle whereas high value items such as golfing and holiday trips support lavish lifestyle. Establishing good rapport is a prerequisite to the rent seeking and giving exchange. Elements which help foster reciprocity by state actors to housing developers ' rentseeking behaviours include low civil servant salary and high living cost, and weak punitive action. Common ethnicity facilitates nuanced communication by the latter, but common religion may dampen the former's enthusiasm to accept any payoffs.
\end{abstract}


Eventually house buyers and the general public are the casualties by virtue of higher house prices and substandard infrastructure. Given the combination of inherent features of the planning system and certain elements that impinge on state actors both of which promote rent-seeking practices, a realistic law enforcement solution is to prioritise illicit market-state exchanges involving grossly distorting rent extraction and pecuniary rewards of significant magnitude rather than total eradication of the practice.

Keywords: approving agencies, development controls, influence buying, payoffs

\section{INTRODUCTION}

In many countries worldwide, housing developers face many challenges when obtaining planning approvals or building permits. The Australian states and territories enacted a series of major planning reform efforts in the new millennium, but bureaucracy and slow decision processes remain (Gurran and Ruming 2016). In Egypt, obtaining a building permit is onerous, bureaucratic and costly (Hassan 2011). Housing developers in England face a lengthy and uncertain period for gaining approval, even when projects conform to planning guidelines (Ball 2011). Developed and developing countries are equally saddled with complex and lengthy procedures for obtaining building permits (World Bank 2013). To influence the planning process outcome, developers spend money and time on lobbying, public relations and consultants (Murray 2012; Ball 2013; Sundaresan 2017). This practice results in deadweight losses for the entire economy, even if it produces specific benefits for local authorities, landowners, developers and consultants. In Ireland, low-level corruption takes place at the local level; individuals and developers lobby, curry favour, or do deals with county councillors and parliamentarians for zoning and permissions in return for support, votes and remuneration of various kinds (favours, kickbacks and fees for "planning consultancy") (Kitchin et al. 2012). The abuse of public offices in connection with planning approval also takes place in Spain (Quesada, Jiménez-Sánchez and Villoria 2013), Egypt (Hassan 2011) and Zimbabwe (Chirisa 2014). In fact, this is a worldwide phenomenon. Transparency International (2013) estimates that, in recent years, every fifth person globally has bribed someone in exchange for land services.

Motivated by the desire to further delve into this worldwide phenomenon, research was embarked on examining the range of issues surrounding the market players and state actors involved in payoffs for influence exchange. Malaysia was used as the location for the research. Because bureaucratic regulatory 
controls involve several approving bodies, it normally takes between a year and two years to obtain planning and construction approval, though a five-year wait is possible (Noni Harianti and Dani 2016). One Stop Centres (OSCs) were introduced in 2007, and the OSC 3.0 planning framework, which is a standard workflow chart for all local authorities, was introduced in 2014. Both target bureaucracy, vague processes and the lack of transparency (Marlyana Azyyati et al. 2019). Even so, the same hurdles remain, compelling housing developers to continue buying influence from approving officers (Foo and Wong 2016; Hamizah, Fatimah and Hazlina 2018). As elsewhere, past research has not fully delved into the entire range of issues pertaining to market-state exchanges. The research questions were:

1. Why do housing developers engage in rent-seeking behaviour?

2. Which agencies are prone to respond to rent-seeking incentives from developers?

3. What are the rent-seeking incentives offered by developers?

4. How are payoffs solicited and delivered?

5. What elements foster the reciprocity of state actors with rent-seeking overtures by housing developers?

6. Which parties suffer from rent-seeking activities?

Following several past studies on land-use planning, the rent-seeking economic model was borrowed to underpin the research. Murray (2012), for example, notes that developers try to establish individual rent-seeking relationships with government officials who have discretionary power to make decisions. Ball evokes the theory when analysing housing developers in Australia, the UK and the USA (2013). In China, Liu and Salzberg (2012) found that rent-seeking behaviour frequently occurs in urban land use and real estate markets with undesirable consequences such as overspeculation. Searle (2016) also employs the rent-seeking concept when describing Australian developers who manage to gain extra developments beyond planning code limits not envisaged by the landowner when the land was sold. Sundaresan (2017) described rampant land use planning violations in Bangalore, India.

Despite studies that have touched on rent-seeking practices in planning approval, Patnaik (2015) laments that rent-seeking behaviour and its distortion regarding the efficient use of resources do not often receive as much public scrutiny as they should when new policies are developed. Furthermore, Hasniyati and Suzila state, "Ultimately, it is not sufficient to only examine the pertinent 
regulations (formal rules) and the network of actor/actor and actor/rules relations (network of relationships) but also the institutionalised behaviour of the actors (informal rules)" (2017, 7). Indeed, Foo (2015) and Foo and Wong (2016) have somewhat unveiled what this paper set out to achieve by examining the informal relationships developers forge with regulatory bodies. This paper enriches our understanding by probing specific areas as framed by the research questions even further. For example, Foo and Wong (2016) dwelled at great length about the informal relationships forged by developers with state actors. However, neither was the practice's pervasiveness among the state actors nor were the elements that drove these state actors to respond to the developers' overtures explored.

\section{RENT-SEEKING BEHAVIOUR}

Although Gordon Tullock introduced the rent-seeking concept in 1967, the term was coined and popularised by Anne Krueger in 1974. "Economic rent" refers to an amount of money earned beyond that which is economically or socially necessary. Tullock (1967) evokes the idea of contestable rent, which induces rentseeking activities aimed at capturing rents. There are many examples of contestable rents, including monopoly rights, protectionist trade policies, privileged budget allocations, income transfers and national resource rights. Their distinguishing feature is that before it is assigned to any economic agent, it is up for grabs. To Tullock, these activities involve unproductive use of real resources, which leads to social loss. Krueger (1974) extends Tullock's work, referring to "rentseeking" as actions directed to obtain special government privileges. There must be two parties involved in the rent-seeking phenomenon: market participants as rent-seekers and government officials as rent-givers. The operational definition of rent-seeking for the research is the quest for developers' privileges from the staff of approving agencies in exchange for unearned payoffs.

Rent-seeking is not synonymous with corruption, although they are often used interchangeably, which is not helpful (Aidt 2016). Corruption is rent-seeking in its illegal and most destructive form (Patnaik 2015). A property developer may expend resources to obtain privileged treatment from the staff of approving agencies but fail, in which case rent-seeking, not corruption, has taken place (Aidt 2016). A developer may blatantly bribe an official without any real resources devoted to unproductive rent-seeking activities, allowing corruption to occur devoid of rent-seeking activities. Rent-seeking is socially wasteful (Laband and Sophocleus 2018) and unproductive (Auriol, Straub and Flochel 2016). Expenditures incurred by rent-seekers can be legal (e.g., lobbying and campaign 
contributions) or illegal (e.g., bribes and coercion) (Patnaik 2015; Grafton and Williams 2020).

Government bureaucrats have little incentive to create and maintain rents if they cannot reap the benefits (Hillman 2015). Rent-seeking arises whenever conditions permit opportunities for private gains to be extracted. Vague and restrictive laws and civil service systems that do not reward officials for honesty and competence are among these conditions (Coolidge and Rose-Ackerman 2000; MartinezGouhier and Petersen 2018). Private individuals and firms are willing to offer payoffs to bureaucrats regardless of their level as long as they can receive special privileges in exchange. Even low-level officials who routinely deal with the public can create their own opportunities to extract rents.

Payoffs to government officials cover anything valuable, from paid meals to valuable gemstones to other items that are easy to convert to cash but difficult to trace (Laband and Sophocleus 2018). They also include entertainment activities to establish a good rapport, such as golfing, rock concerts and hunting or fishing trips. In return, individuals and private companies benefit from speedy administrative processes and the avoidance of artificially imposed hurdles.

Rent-seeking theory, however, is not without its critics. Samuels accuses rentseeking theorists of operating "in an arena of analytical ambiguity" $(1992,125)$. Space limitations do not allow the critiques to be elaborated. Addressing forceful criticisms by Samuels and Mercuro (1986) and North (1986), Rowley (2013) suggests that with careful treatment, rent-seeking theory makes an important contribution to public choice schools. As with recent scholars (Grafton and Williams 2020; Larrain and Perello 2020), this paper borrows the basic rent-seeking concept only to the necessary extent. Samuels admits that if the discussion is limited to the advantage-seeking activity taking place and that if it affects society's welfare, "there would be little if anything over which to quibble" $(1992,113)$.

\section{The Housing Development Approval Process in Malaysia}

This section provides information crucial for understanding the research findings. As in most countries, housing developers in Malaysia must obtain planning and construction approvals before houses can be erected on site. Consultants engaged by property developers usually carry out submissions for approval.

The housing development approval process is governed by three administrative layers at the federal, state and local levels, which actually malign efficient government services (Ibrahim, Faizah and Ezrin 2011). The federal government 
has enacted more than 20 pieces of legislation that govern housing development, ranging from laws on land and buildings to the environment. As enshrined in the Federal Constitution, state governments have exclusive power over land within their jurisdiction (Hasniyati and Suzila 2017). Housing developers are also required to comply with planning guidelines prepared by the state, which incidentally are dissimilar to one another (Foo 2015; Foo and Wong 2016). Planning permission can only be obtained from local planning authorities (Marlyana Azyyati et al. 2019).

Obtaining approval usually takes between a year and two years, but the duration may extend up to five years (Noni Harianti and Dani 2016). Recurring submissions because of requirement amendments are common (Marlyana Azyyati et al. 2019). The delay emanates not only from the planning department but also from other related technical departments, approximately 20 in all, which developers potentially must consult (Ibrahim, Faizah and Ezrin 2011). Slow progress in local government services, cumbersome procedures, sluggish approval and a lack of coordination amongst government agencies have been attributed to higher development costs (Noni Harianti and Dani 2016; Marlyana Azyyati et al. 2019).

Such malaise persists despite the 2007 introduction of OSCs designated to improve the fragmented and bureaucratic approval system at the local level (Foo and Wong 2014; Marlyana Azyyati et al. 2019). On 1 June 2014, the government enforced the OSC 3.0 framework, criticised for still being cumbersome (Hamizah, Fatimah and Hazlina 2018). For new development sites, developers are required to submit development and building plans simultaneously to the OSC. Upon receiving those plans, the OSC circulates them to all relevant internal and external departments as well as privatised utility companies. These approving bodies have 14 days to respond, failing which the applications are deemed approved. Upon receiving comments from the respective technical departments, the OSC officers prepare reports which the planning committee uses for decisions. The OSC meeting, which is supposed to convene regularly, is attended by the approving departments' directors. Developers view the supposedly fast-tracking OSC as a cosmetic change to the previous system (Foo and Wong 2014; Marlyana Azyyati et al. 2019).

Many of the previous shortcomings remain, resulting in delays in planning approvals, among others (Hamizah, Fatimah and Hazlina 2018; Marlyana Azyyati et al. 2019). OSC meetings may be infrequent or even cancelled (Foo and Wong 2016). Directors who attend the OSC meeting may disagree with the conditions set by the officers that have already discussed a project with its developers (Foo and Wong 2014; 2016). The lack of clarity in the planning 
framework paves the way for planning officers to exert their own subjective interpretation (Foo and Wong 2014). The Town Planning Committee or the State Planning Authority may also impose amendments for design aspects such as density, community facilities and infrastructure (Foo and Wong 2016). Worse, state executive councils comprising councillors, some without professional planning backgrounds, overrule the advice by state planning departments and release planning approvals (Foo 2015).

Planning staff, usually diploma holders, are not always technically trained in planning matters (Foo and Wong 2014; Foo 2015). Furthermore, the lack of staffing that many cash-strapped local authorities endure results in bottlenecks (Hamizah, Fatimah and Hazlina 2018; Marlyana Azyyati et al. 2019). Generally, local authorities receive minimal fiscal transfers from federal and state levels and must rely on own-source revenues (World Bank 2015). Only larger cities can employ technical and professional staff and have their own technical departments (Ibrahim, Faizah and Ezrin 2011).

In the face of various criticisms, approving bodies blame delays on planning consultants for not fully adhering to government guidelines (Noni Harianti and Dani 2016), even deliberately omitting certain planning requirements, all to drive up their profits (Foo 2015; Foo and Wong 2014; 2016).

Contrary to OSCs' intended purpose, developers revert to the old practice of directly sending their plans to all relevant departments for more accurate and speedy feedback (Foo and Wong 2014). To tackle bureaucracy, lengthy application processes and subjective interpretation by planning officials, developers usually assign one staff member as a dedicated "professional liaison officer" (Foo and Wong 2014; 2016). Queue jumping for speedy approval and negotiations for waivers or relaxation of planning requirements are commonly deployed tactics. Foo and Wong $(2014 ; 2016)$ note that "guanxi" (informal relationships these liaison officers forge with approving officers) may infringe on ethical issues.

\section{RESEARCH METHOD}

This research adopted a qualitative approach, as it allows for a "deeper" understanding of social phenomena than would be obtained from a purely quantitative method (Silverman 2014). This study interviewed experts who were derived from purposeful sampling. Experts possess practical insider knowledge and act as surrogates for a wider circle of players (Bogner, Littig and Menz 2018). Sixteen of the interviewees were referred to by friends in the 
industry. The remaining six were from snowball sampling. People of different categories (i.e., private housing developers and consultants) in different locations were interviewed (see Table 1). Both actions served to triangulate for a fuller picture of the situation, thereby increasing the findings' validity (Natow 2019). Further attempts to obtain respondents in every state throughout Peninsular Malaysia were not met. Nevertheless, data saturation was reached by the time the 22 interviews were completed (Saunders et al. 2018). This sample size cohered with what scholars recommend (Francis et al. 2010; Creswell 2014).

Table 1: Respondents' details

\begin{tabular}{|c|c|c|c|c|}
\hline ID & Position & Company & State & $\begin{array}{l}\text { Years of } \\
\text { experience }\end{array}$ \\
\hline 1 & Engineer & C\&S consultant & Pulau Pinang & 30 \\
\hline 2 & Engineer & $\mathrm{C} \& \mathrm{~S}$ consultant & Pulau Pinang & 5 \\
\hline 3 & Project executive & Private developer & Perak & 12 \\
\hline 4 & Architect & Architect consultant & Pulau Pinang & 8 \\
\hline 5 & General manager & Private developer & Kedah & 24 \\
\hline 6 & Project executive & Private developer & Perak & 4 \\
\hline 7 & Engineer & M\&E consultant & Selangor & 3 \\
\hline 8 & Architect & Architect consultant & Kuala Lumpur & 4 \\
\hline 9 & Project executive & Private developer & Selangor & 14 \\
\hline 10 & Architect & Architect consultant & Kuala Lumpur & 12 \\
\hline 11 & Project executive & Private developer & Kuala Lumpur & 20 \\
\hline 12 & Authority liaison officer & Private developer & Kuala Lumpur & 23 \\
\hline 13 & $\begin{array}{l}\text { Chief operating officer- } \\
\text { operations }\end{array}$ & Private developer & Kuala Lumpur & 28 \\
\hline 14 & Authority liaison officer & Private developer & Kuala Lumpur & 18 \\
\hline 15 & Project executive & Private developer & Pahang & 15 \\
\hline 16 & Architect & Architect consultant & Terengganu & 20 \\
\hline 17 & Architect & Architect consultant & Terengganu & 9 \\
\hline 18 & General manager & Private developer & Kelantan & 13 \\
\hline 19 & General manager & GLC developer & Kelantan & 23 \\
\hline 20 & Assistant general manager & Private developer & Terengganu & 8 \\
\hline 21 & Project executive & Private developer & Kelantan & 14 \\
\hline 22 & Architect & Architect consultant & Kelantan & 15 \\
\hline
\end{tabular}


There is no "best way" to conduct expert interviews (Bogner, Littig and Menz 2018). The interviews were semi-structured based on an interview guide derived from the research questions, though probing questions arising from unexpected responses were also posed (Roulston and Choi 2018). The information sought pertained to technical knowledge (i.e., facts about operations and events), process knowledge (information about sequences of actions) and interpretative knowledge (points of view and interpretations) (Bogner, Littig and Menz 2018). The conversations began with small talk so that the interviewees would be at ease (Cayleff et al. 2011; Jentoft and Olsen 2019). This lasted between 10 minutes to 20 minutes. Words and intonation were also carefully selected throughout the interviews to maintain established rapport (Condie 2012; Prior 2018).

Both tape-recording (with permission from interviewees) and note-taking (especially for nonverbal information) were undertaken during the sessions, except for two interviewees who objected to the former. Some requested that the tape recorder be switched off at certain times during the interviews. The researchers were culturally competent in picking up nuanced responses and nonverbal communication (Pelzang and Hutchinson 2017). All the responses were compiled and analysed before the next interview. Data collection and data analysis went hand in hand, enabling new ideas or patterns to emerge until the data were fully saturated (Lawrence and Tar 2013; Saunders, Lewis and Thornhill 2016). Interviewees were asked to explain if their answers differed from those of their predecessors. Hence, the range of questions expanded as the interview sessions progressed (Saunders, Lewis and Thornhill 2016). As the data became saturated, key issues started to bear resemblance (Morse 2015). All interviews lasted between 45 minutes and two hours.

The researchers faced several challenges, including responses that had nothing to do with the questions posed and negative comments such as the subject matter that should not have been researched. One possible explanation for such adverse communication is the patronising attitude from people accustomed to being "in charge" and listened to by others (Bogner, Littig and Menz 2018). The interview process took more than a year, initially because some took quite some time to agree (up to three months), after which interview schedules had to be mutually convenient, especially for out-of-state trips. There was one occasion when an interview was cancelled upon arrival in Pahang because the respondent was busy.

Transcription of tape recordings was performed verbatim as the data were collected. For bahasa Malaysia speaking informants, translation was done into English. Although laborious, transcript-based analysis is the most efficient way 
of drawing out key themes and subthemes related to the research questions (Nowell et al. 2017). Atlas.ti8 text analysis software helped the analytical process by allowing selected texts to be digitally labelled using own-defined codes. Altogether, 1,532 coded text segments using 91 code labels were generated and organised to tie those key themes and subthemes together. Analysis of the themes then ensued.

According to Creswell (2014), interviewing reliability is elusive and no study reports actual reliability data. Nonetheless, attempts were still made to achieve some degree of reliability and validity. An adequate and appropriate sample was framed, identical questions (barring follow-up questions) were posed, leading questions were refrained from, clarification was sought if needed, note-taking and tape recording ran concurrently, and data were recorded in a structured manner as precisely as possible (Alshenqeeti 2014; Morse 2015; Saunders, Lewis and Thornhill 2016; Yin 2016).

\section{FINDINGS}

This findings section is divided into sections based on the set of research questions.

\section{Reasons Developers Engage in Rent-Seeking Behaviours}

This subsection describes the barriers that housing developers face during the approval process that prompts them to engage in rent-seeking behaviours.

The OSC 3.0 approving regime is said to be worse than its predecessors, as it imposes additional processes, some of which are said to be repetitive, trivial and unnecessary. For example, the required pre-consultation meetings before submission still fail to end the cycles of amendments. The overall approval process can take up to two years, well beyond the two weeks' duration stipulated by OSC 3.0. The delay can be genuinely attributed to bureaucratic procedures, workforce shortages and the sheer numbers of applications combined. However, the interviewees stressed that it is also exacerbated by rent-creating strategies devised by self-serving bureaucrats, such as vacillating decisions and "missing" files, inducing housing developers who want prompt feedback or accelerated processing to adopt a rent-seeking stance. "One has to kneel, plead or do practically anything to get approval", complained Interviewee 14.

In general, staff of approving agencies have gained notoriety for being irresponsible with files going missing or getting stuck in the system, as well as 
being incompetent or unwilling to keep abreast with new policies. Interviewee 14 said, "We see them today, they give comments, then we redo and resubmit the next day. They then say that they have received new amendments which they forgot to tell us." Interviewee 18 complained, "The worst situation is when they pretend as if they know things when in fact they don't." Whether deliberate or real, acts of irresponsibility and incompetency impose difficulties on applicants. It might not be too harsh to suggest that offending public servants reassign their talents for devising rent-creation strategies rather than improve work performance.

Local authorities have wide discretionary power bestowed by the Street, Drainage and Building Act 1974 and Town and Country Planning Act 1976. As such, they are permitted to modify their procedures and requirements. This power also allows self-serving bureaucrats to impose unreasonable reviews and make arbitrary decisions. Interviewee 4 narrated the uncertainties his company once faced:

There was this situation when the staff of an approving agency did not inform us properly what they wanted. Therefore, when we checked the result...not approved...whereas we had already followed up with the front desk personnel before this, and he said everything followed the guidelines...so it was surprising when we failed.

Thus, compliance with bylaws and regulations does not guarantee approval. Developers have the right to appeal against unreasonable or arbitrary decisions, but succeeding is another matter. Interviewee 4 narrated that on one of his past projects, the road corridor was designed to meet the minimum 1.2-metre wide requirement. However, the building department inexplicably insisted that it was 1.5 metres.

At times, daring developers try their luck by submitting plans that contravene approving authorities' requirements and regulations in the hope they can get away by assuaging the wants of compromised bureaucrats. Interviewee 16 said, "Better to give RM10,000 than to build an RM100,000 monsoon drain."

Some developers try to pin down the approving officers on the decisions they made by having face-to-face meetings. Such appointments may even come at a price to overcome excuses such as "many files to go through, meetings, not in the office, outstation, sick children, etc.", said Interviewee 5. Some low-level support staff try to prevent applicants from dealing directly with their superiors so that they can extract rents. 
To summarise, whether real or artificial, housing developers face all kinds of difficulties when applying for housing development approval. They are driven to engage in rent-seeking behaviour for prompt feedback, expeditious processing, unreasonable review evasion, arbitrary decision avoidance, flexibility in compliance with requirements and even appointments with approving officers.

\section{Agencies Prone to Rent-Seeking Incentives from Developers}

To overcome delays, some OSCs permit applicants to deal directly with approving agencies, a throwback to past practices whereby many parties can make personal gains from rent creation.

The Town and Planning Department was mentioned as being the most frequent to solicit rent-giving incentives from developers. According to Interviewee 14, this department has the widest discretionary power; hence, the avenue for rent extraction is greatest. The engineering department was the next most frequently cited offending body, followed by the building department. Seven out of the 18 approving agencies were not mentioned, though this omission was because the participants had not dealt with them before. Suffice to say that the practice of extracting rents cuts across all approving agencies, including utility companies.

The staff of these approving agencies are generally made up of approving officers and low-level support staff. The power to approve rests with approving officers (designated directors or deputy directors). Members of the support staff (technicians and assistant staff) occupying the counters are the first points of contact when submitting plans. Though unsanctioned, low-level staff give firsthand advice to applicants. Their legitimacy rests on the public perception that they are knowledgeable. Both approving officers and support staff are culpable for creating rents either conspiratorially or independently. Support staff have been known to resent applicants and bypass them because of lost opportunities for rent extraction. They might arrange for direct contact with approving officers at a price. However, applicants must be prepared for a backlash, cautioned Interviewee 5, who on one occasion became exasperated when his submission to one agency did not make any progress for several months, which was interpreted as a hint by the support staff for a bribe. "When we met the head of the department directly, the problem was resolved in two days only, so what do you make of it?" he asked. It must be pointed out that not all bureaucrats are party to rent extraction. Separately, two interviewees estimated that three out of 10 staff of approving agencies are ethical. 


\section{Rent-Seeking Incentives}

The monetary value of payoffs to remove barriers varies according to four factors: rank of staff in approving agencies, location of projects, size of projects and project complexity. The higher the level of the bureaucrat is, the larger the payoff he can demand. Interviewee 8 evoked the analogy of "small baits catch small fishes and big baits catch big fishes". The monetary value of the payoffs ranges from a few hundred to thousands of Malaysian Ringgit. Interviewee 2 admitted to paying between RM7,000 and RM15,000 to directors in exchange for rules to be bent.

Location also determines the value of the payoffs. In suburban areas, the requirements to obtain approval are less complicated. In addition, there are fewer applications. Hence, the opportunity to create rents is constrained. Interviewee 6 indicated that her company deliberately moved out of Malaysia's capital, Kuala Lumpur, because the payoffs became financially untenable. Interviewee 9 indicated that one of the local authorities in Selangor (the most economically active state in Malaysia) demanded payoffs valued in thousands of Malaysian Ringgit. Larger and more complex development projects also command higher payoffs. For a dual-tower project comprising offices and service apartments (one of 14 storeys, the other 32 storeys), Interviewee 10's company paid between RM20,000 and RM30,000 to obtain approval within two weeks.

The forms the payoffs take vary, with differing requests for cash or material items. At the time of the study, the amount of cash was between RM1,000 and RM3,000. As festive goodwill, developers are expected to give monetary gifts and hampers. Food treats can range from canned drinks to sumptuous meals. Household items such as television sets, kitchen cabinets, air-conditioning units and satellite TV installations are common requests. So too are car-related items such as repairs, maintenance and modifications, as well as new tyres and tinted glass. Personal items range from laptops, watches, jewellery, mobile phones, smoking pipes and handbags to mobile phone top-up credits. Informants were coy when asked about escorts that some approving staff have a penchant for. The more expensive payoffs include golf or holiday trips, house discounts, new cars and, in rare cases, new houses. According to Interviewee 15, house discounts ranged from RM20,000 to RM30,000. Legitimate payoffs include donations, charities for good causes and sponsorship of club activities.

Developers play along with requests from bureaucrats as long as the economic benefits outweigh the rent-seeking costs. Once the ingratiating behaviour ends after the tipping point is crossed, obtaining planning approvals becomes challenging. 
The developers would most likely be cold-shouldered by disgruntled approving staff. The latter may even tell their colleagues in other approving agencies to blacklist such companies, jeopardising ongoing and future projects.

\section{Payoffs Offered and Delivered}

This subsection deals with how payoffs are solicited and delivered. Communication can be direct or discreet. Generally, if the payoffs are of small monetary value, communication is direct. For large-cost items, communication tends to be discreet. Interviewee 15 observed that low-value items serve to support a normal lifestyle, whereas high-value items embody a lavish lifestyle.

As an initial step, market players must establish a good rapport with approving staff to gauge their responsiveness to rent-seeking incentives. The last thing the former wants to do is offend the latter by misjudging their character (as indicated earlier, not all engage in rent-giving practices). Even offending public actors want to be treated with "respectability". Interviewee 8 narrated how he, after chasing approval "many times", blatantly asked the staff member what he wanted. The latter went silent and later messaged him on WhatsApp asking for RM1,000. Such bluntness could have backfired.

In contrast, staff of approving agencies do not need to invest in relationship building to make their requests known. They may drop hints, the usual being artificial difficulties such as approval delays. Applicants must interpret nuanced language and actions to determine the corrupt staff member's true intent. As Interviewee 1 explained, "We amended three to four times...not approved... it is normal, and we know all their tricks...they expected something from us." The second indirect signal is narrating to the applicant their predicament, such as a car needing repair. Communication may be made through phone, face-to-face conversation, short message service (SMS) texts or social media.

Consultants engaged by developers to submit plans only limit themselves to meal treats; more expensive requests by compromised officials are passed on to the developers. Small developers normally assign a project leader or runner to deal with such people. Runners are temporarily appointed with the sole purpose of obtaining planning approval. They are familiar with the staff of approving agencies on a personal level. Larger and established development companies usually have permanent authority liaison officers to perform the same task.

Underhanded transactions occur either surreptitiously (outside the office during off-hours) or overtly (in the office during office hours), depending on the 
recipient's preference. For golfing or holiday trips, the staff of the developer would accompany the officials. Interviewee 11 explained, "It is our company policy. We do not give them cash... because it is difficult to record our expenses later. Therefore, if they go with our staff, there is no issue. No one queries the expenses." The developers' top management would step in to deal directly with the public actors involving payoffs related to escorts, new cars, or big items.

\section{Elements That Foster Reciprocity by State Actors Regarding the Rent- Seeking Behaviours of Housing Developers}

We next examined the elements that foster rent-seeking reciprocity by state actors. These elements revolve around persons and institutions.

The informants rationalised that a low government salary and high living costs, especially in urban centres, drive the staff to supplement their income. Interviewee 13 said, "Look at the expenditure for family, food, children, schooling, house, car, etc. This is the root cause of their behaviour." At the same time, there is the view that some simply have weak moral fibre, allowing greed and desire for a lavish lifestyle to overcome their moral inhibitions. Interviewee 18 said, "They know they can get what they ask for. They are greedy. If not enough, they know they can always ask for more. These type of people exist." Such public servants make no attempt to conceal their lavish lifestyles, taking expensive holiday trips and purchasing imported cars.

The interviewees accused those at the top of the hierarchy of breeding rentgiving culture (Interviewee 13 quoted the Chinese proverb, "The fish rots from the head"). Interviewee 4 observed that anyone unwilling to comply with rent extraction practice was ostracised by his offending colleagues. The culture is so entrenched that it can withstand staff retirements and replacements (job rotation, if practised at all, only affects approving officers, not support staff). While some interviewees pinned their hopes on the young generation to behave ethically, the cynical speculated that they would eventually succumb to the overbearing rentgiving culture.

The interviewees cited a few reasons for not reporting public office abuse to the Malaysian Anti-Corruption Commission (MACC), which investigates and prosecutes corruption. The protracted effort of reporting with no guaranteed justice is the first. The perception that coming up with strong evidence against the alleged perpetrators is difficult is another. In addition, their companies were culpable for unlawful transactions. Market players give in to self-serving bureaucrats for as long as they can profit from their development ventures. 
The interviewees were also concerned about possible retaliation for reporting to the MACC. Interviewee 8 said, "If we report, the staff can blacklist our projects. They have friends in other approving agencies. Word gets around... so difficult for us." Dishearteningly, the few past public actors caught abusing public trust were only transferred to different authorities or suspended temporarily. Light punishment meted out to offenders flies in the face of public sector integrity. Finally, there is sympathy for approving staff who have to supplement their low income through rent extraction to meet high living costs.

Ethnicity influences rent-seeking dynamics. Common ethnicity between public actors and runners or authority liaison officers facilitates nuanced communication. Working in favour of developers, common religion may help dampen the exuberance of approving staff for rent extraction. Both diametrically opposing forces-common ethnicity and religion-often work in unison between the market player and state actor, producing unpredictable outcomes.

\section{Casualties of Rent-Seeking Activities}

Property developers allocate expenditures ranging from $1 \%$ to $10 \%$ of their development budgets for rent-seeking, depending on the top management's judgement and the projects' features. Two interviewees said their companies did not make any financial provision, as the amount was too small. Unused allocation was treated as profit. To avoid financial detection by auditors, rent expenditures are classified as entertainment costs, processing fees, contingency costs, marketing costs, administrative costs or miscellaneous costs.

There are also indirect costs related to rent-seeking activities. Regardless of how small, consultants surely inflate their fees to account for likely light expenses on rent-creating public officials. There is also a cost implication when developers and their staff need to adjust to subtle variations in the approval process with unfamiliar local authorities. Unlike such one-off expenses, engaging runners or authority liaison officers is a recurring expenditure. Top management's valuable time is wasted when entertaining rent-creating officials.

These direct and indirect expenses inflate housing development costs and ultimately house prices. The impact of rent-seeking behaviour by housing developers, however, transcends beyond house buyers. When conniving developers manage to get approving authorities to compromise infrastructure, the general public suffers. Surface water drainage with smaller capacities court flash floods, narrower road reserves compromise the safety of pedestrians and vehicles alike, 
undersized sewerage treatment plants pose health and environmental hazards, and decreased open spaces impair the public's proclivity for regular exercise.

While house buyers and the public are made to absorb the negative ramifications of housing developers' rent-seeking behaviour, the benefits thereof are enjoyed solely by the latter. These benefits include accelerated approval and less bureaucracy, which translates to lower holding and administration costs. Savings are also made whenever developers manage to bend the rules, such as by providing less public infrastructure.

\section{DISCUSSIONS}

In this section, the findings of the study are contrasted with past publications. In doing so, the contributions of this research are made clear.

The study affirms past observations by Malaysian scholars (Noni Harianti and Dani 2016; Marlyana Azyyati et al. 2019) that the developers' woes continue despite the introduction of OSC and the OSC 3.0 planning framework. Some of the challenges approving authorities face are genuine (Ibrahim, Faizah and Ezrin 2011; Hamizah, Fatimah and Hazlina 2018); the sheer volume of work they must handle has never been suggested by scholars as one of them. Equally from this study, it cannot be ruled out that hurdles are mere ploys by state actors to extract payoffs, a possibility that has also avoided past scholastic attention. Officials with wide discretionary powers have been noted before (Foo and Wong 2014). However, the power to overrule compliances by developers is another new observation. The study also brings greater clarity to the reasons why developers engage in rent-seeking behaviour. One previously unobserved motive is to circumvent excuses so that meetings with decision-makers can take place.

Foo and Wong (2016) point to informal relationships developers forge with approving authorities, but horizontal networks spanning all approving agencies have never been articulated. The study found that not all state actors are unethical. The ethical are certainly the deviants.

The study found that the form of pecuniary rewards that compromised state actors' request extends beyond small dinner and golf games (Foo and Wong 2016). It also reveals that the monetary value of those rewards is tied to certain factors such as the rank of the staff and project-related aspects (i.e., location, size and complexity). 
Chiodelli and Moroni (2015) note that how much can be extracted from rents depends on how much developers stand to gain. The study extends this proposition by indicating that there is a limit to which developers can tolerate the requests of rent-givers, how developers react once economic returns are overwhelmed by rent-seeking costs, and how compromised staff members respond to such reactions.

The nuanced communication involved when payoffs are offered for the first time, the limits to which consultants become involved in the transactions, and how transactions are completed are another contribution of this research. Likewise, the developer's staff accompanied the golfing or holiday trips and top management was involved with certain payoff items. People skilled in networking are utilised to smoothen the development process elsewhere (Adams, Dunse and White 2005). In Malaysia, they are referred to as professional liaison officers (Foo and Wong 2014; 2016), or as the study found, runners.

Aspects that foster reciprocity by state actors to rent-seeking overtures have never been fully explored. In Spain, a toxic combination of a high degree of autonomy and little accountability pressure accounted for widespread rent extracting behaviour (Quesada, Jiménez-Sánchez and Villoria 2013). This study found that a combination of low salary coupled with high living costs, desires for lavish lifestyles, a deeply embedded rent-giving culture, non-reportage by developers to the MACC and light internal penalties for caught offenders led to similar outcomes. As long ago as 1954, Rogow warns of government officials succumbing to market players in situations where "their rank and salary are disproportional to the character of their work and the amounts involved" (p. 11). Public officials committing immoral deeds out of greed have long been documented (Thompson 1987). Past studies have examined the correlation between ethnicity (Pande 2007) and religion (Samanta 2011; North, Orman and Gwin 2013) on corruption. However, the study is the first to come across the confluence of both within rentseeking settings.

The final contribution of this article is the articulation of financial and nonfinancial ramifications as a consequence of rent-seeking practices. Rentseeking expenditure, when included in development budgets (up to $10 \%$ markup), implies that it is eventually transferred to house buyers. The indirect costs (e.g., higher consultancy fees, salaries of runners or authority liaison officers, and operational and top management's time and effort) are equally transferred. Another notable deleterious effect is societal welfare loss due to substandard infrastructure and facilities. 
Returning to the theory on rent-seeking, in 1980, Tullock points to the paradox in his concept, which he (Lockard and Tullock 2001) later revisits. He found that total rent-seeking expenditures are much lower than the gains made from rentseeking activities, contrary to predicting that expenditures should rise to the prize's value. Possible explanations involving politicians include an inhibition for accepting large payoffs or leading lavish lifestyles for fear of reprisal from voters and competition for payoffs, which reduces the cost of rent-seeking (Zingales 2014). Various scholars (Hehenkamp, Leininger and Possajennikov 2001; Vogt, Weimann and Yang 2002; Dari-Mattiacci and Parisi 2005) have attempted to address this puzzle.

The findings from the study do not support the rent-seeking paradox. Corrupt officers have been known to request as much as possible to the extent that developers have had to put a stop to their generosity, thereby risking ongoing and future projects. The paradox breaks down because developers have no one else to turn to while operating within the corrupt officers' jurisdiction. Weak legal sanctions and weak internal disciplinary actions serve as ineffectual deterrence.

\section{CONCLUDING THOUGHTS}

There are implications of this study at two levels. Theoretically, by answering the six research questions, the study shows that the rent-seeking concept is a useful theoretical lens for conducting a fine-grained examination of the rent-seeking behaviour of property developers in Malaysia. However, it also indicates that the rent-seeking paradox is not applicable in the given context.

Empirically, the study shows how intricate and deeply embedded rent-seeking practices are in Malaysia's planning approval process. Developers countenance support for rent-givers struggling with low income and high living expenses while at the same time addressing the asymmetrical relationships with state actors in the only way they know how to. It is probably fair to say that the findings of this study are likely to resonate with the regulatory planning process of other countries where the same rent-seeking practices have also been institutionalised.

Chiodelli and Moroni (2015) aim to incentivise certain behaviour from housing developers in the planning system itself. They believe that developers are not in themselves more prone to corruption than entrepreneurs in other economic spheres. Gardiner (1985) equally suggests that a variety of opportunities for corruption are built into land use and building regulatory systems. Unless Malaysian 
policymakers can address this issue within the regulatory planning system together with the elements that foster reciprocity by state actors concerning rent-seeking overtures, any attempt to fully eradicate it would be futile. Though it would collide with public sensibilities, a more realistic solution is that with the limited available resources, law enforcement agencies, especially the MACC, should prioritise illicit market-state exchanges involving grossly distorted rent extraction pecuniary rewards of significant magnitude. Our suggestion is not peculiar, as it might sound like prioritisation when policing crime occurs (Mann 2017; Doig 2018). Our suggestion does not mean that we condone rent-seeking practices of whatever form in development approval. It is based on what is realistically achievable under various constraints.

There are certain limitations to this study. The obvious one is the exclusion of the public actors from interviews (although getting them to own up to their malfeasance would not be easy). The entirety of Peninsular Malaysia was not covered as originally intended, either. To enrich the study further, the states of Sarawak and Sabah should also be included.

In the future, to generalise the findings, a nationwide questionnaire survey should be carried out involving a larger sample. This research has generated several lines of enquiries that can benefit from future investigations so that land-use planning violations can be further explored, one of which is the interplay of common religion and ethnicity between market and state actors. As informal relationships play an important role in rent-seeking dynamics, future studies may want to consider using network theory as the next theoretical backdrop.

\section{ACKNOWLEDGEMENTS}

This work was supported by the Ministry of Education Malaysia under the Fundamental Research Grant Scheme (FRGS/1/2015/SSI11/USM/01/1) administered by Universiti Sains Malaysia.

\section{REFERENCES}

Adams, D., N. Dunse and M. White. 2005. Conceptualising state-market relations in land and property: The growth of institutionalism - extension or challenge to mainstream economics? In Planning, public policy and property markets, eds. D. Adams, C. Watkins and M. White, 17-36. Oxford: Blackwell. 
Aidt, T.S. 2016. Rent seeking and the economics of corruption. Constitutional Political Economy 27(2): 142-157. https:/doi.org/10.1007/s10602-016-9215-9

Alshenqeeti, H. 2014. Interviewing as a data collection method: A critical review. English Linguistic Research 3(1): 39-45. https://doi.org/10.5430/elr.v3n1p39

Auriol, E., S. Straub and T. Flochel. 2016. Public procurement and rent-seeking: The case of Paraguay. World Development 77: 395-407. https://doi.org/10.1016/ j.worlddev.2015.09.001

Ball, M. 2011. Planning delay and the responsiveness of English housing supply. Urban Studies 48(2): 349-362. https://doi.org/10.1177/0042098010363499

2013. Spatial regulation and international differences in the housebuilding industries. Journal of Property Research 30(3): 189-204. https://doi.org/10 $.1080 / 09599916.2013 .791338$

Bogdan, R. and S.K. Biklen. 1997. Qualitative research for education. Boston, MA: Allyn \& Bacon.

Bogner, A., B. Littig and W. Menz. 2018. Generating qualitative data with experts and elites. In The SAGE handbook of qualitative data collection, ed. U. Flick, 652-667. London: Sage Publications Ltd. https://doi.org/10.4135/97815264160 $70 . n 41$

Cayleff, S., M. Herron, C. Cormier, S. Wheeler, A. Chávez-Arteaga, J. Spain and C. Dominguez. 2011. Oral history and "girls' voices": The young women's studies club as a site of empowerment. Journal of International Women's Studies 12(4): 22-44.

Chiodelli, F. and S. Moroni. 2015. Corruption in land-use issues: A crucial challenge for planning for planning theory and practice. Town Planning Review 86(4): 437455. https://doi.org/10.3828/tpr.2015.27

Chirisa, I. 2014. Building and urban planning in Zimbabwe with special reference to Harare: Putting needs, costs and sustainability in focus. Consilience 11: 1-26.

Condie, J. 2012. Beyond rationalisations: Improving interview data quality. Qualitative Research in Accounting \& Management 9(2): 168-193. https://doi.org/10 $.1108 / 11766091211240379$

Coolidge, J. and S. Rose-Ackerman. 2000. Kleptocracy and reform in African regimes: Theory and examples. In Corruption and development in Africa, eds. K.R. Hope Sr and B.C. Chikulo, 57-86. London: Palgrave Macmillan. https://doi .org/10.1057/9780333982440_4

Creswell, J.W. 2014. Research design: Qualitative, quantitative and mixed methods approaches. 4th ed. London: Sage Publications.

Dari-Mattiacci, G. and F. Parisi. 2005. Rents, dissipation and lost treasures: Rethinking Tullock's paradox. Public Choice 124(3-4): 411-422. https://doi.org/10.1007/ s11127-005-2056-0

Doig, A. 2018. Implementing national policing agendas and strategies for fraud at local level. Journal of Financial Crime 25(4): 984-996. https://doi.org/10.1108/JFC -04-2017-0027

Fischer, P. 2006. Rent-seeking, institutions and reforms in Africa. Theory and empirical evidence from Tanzania. New York: Springer Science+Business Media. 
Foo, J.H.R. and C. Wong. 2014. Planning for housing development in Malaysia: Developers' response to the regulatory policy framework. International Planning Studies 19(2): 192-209. https://doi.org/10.1080/13563475.2014 .885832

2016. The informal 'guanxi' institutional culture of the Malaysian housing development industry. Planning Practice \& Research 31(3): 292-310. https://doi.org/10.1080/02697459.2016.1174971

Foo, R. 2015. Barriers to building institutional capacity in the Malaysian housing development sector. International Journal of Housing Policy 15(4): 436-460. https://doi.org/10.1080/14616718.2015.1057428

Francis, J.J., M. Johnston, C. Robertson, L. Glidewell, V. Entwistle, M.P. Eccles and J.M. Grimshaw. 2010. What is an adequate sample size? Operationalising data saturation for theory-based interview studies. Psychology and Health 25(10): 1229-1245. https://doi.org/10.1080/08870440903194015

Gardiner, J.A. 1985. Corruption and reform in land-use and building regulation. In Ethics in planning, ed. M. Wachs, 121-142. New Brunswick: Transaction Publishers. https://doi.org/10.4324/9781351311366-9

Grafton, R.Q. and J. Williams. 2020. Rent-seeking behavior and regulatory capture in the Murray-Darling Basin, Australia. International Journal of Water Resources Development 36(2-3): 484-504. https://doi.org/10.1080/07900627 .2019.1674132

Gurran, N. and K. Ruming. 2016. Less planning, more development? Housing and urban reform discourses in Australia. Journal of Economic Policy Reform 19(3): 262-280. https://doi.org/10.1080/17487870.2015.1065184

Hamizah Yakob, Fatimah Yusof and Hazlina Hamdan. 2018. Expert views on strategies in ensuring effectiveness of housing planning and control activities. Asian Journal of Behavioural Studies 3(13): 68-77. https://doi.org/10.21834/ajbes. v3i13.144

Hasniyati Hamzah and Suzila Mislam. 2017. Local building regulators' institutionalised behaviour towards mass customised housing (MCH). International Journal of Property Science 7(1): 1-19. https://doi.org/10.22452/ijps.vol7no1.2

Hassan, G.F. 2011. The enabling approach for housing supply. Drawbacks and prerequisites - Egyptian experiences. Alexandria Engineering Journal 50: 421-429. https://doi.org/10.1016/j.aej.2012.01.007

Hehenkamp, B., W. Leininger and A. Possajennikov. 2001. Evolutionary rent-seeking. CESifo working paper no. 620, December, Munich, Germany, CESifo. http://papers.ssrn.com/abstract $=296117$ (accessed 8 April 2020).

Hillman, A.L. 2015. Rent seeking as political economy. In Companion to the political economy of rent seeking, eds. R.D. Congleton and A.L. Hillman, 10-13. Cheltenham, UK: Edward Elgar Publishing.

Ho, C.S. 2003. Land laws and their impact on housing. In Housing the nation: Policies, issues and prospects, 187-204. Kuala Lumpur: Cagamas Holdings Berhad. 
Ibrahim Mohd@Ahmad, Faizah Ahmad and Ezrin Arbi. 2011. One stop centre as a boon to property development approval process. A case study: City Hall of Kuala Lumpur. Journal of Design and Built Environment 8(1): 1-14. https://ejournal .um.edu.my/index.php/jdbe/article/view/5308/3101 (accessed 4 August 2019).

Jentoft, N. and T.S. Olsen. 2019. Against the flow in data collection: How data triangulation combined with a 'slow' interview technique enriches data. Qualitative Social Work 18(2): 179-193. https://doi.org/10.1177/14733250177 12581

Kitchin, R., C. O’Callaghan, M. Boyle, J. Gleeson and K. Keaveney. 2012. Placing neoliberalism: The rise and fall of Ireland's Celtic Tiger. Environment and Planning A 44: 1302-1326. https://doi.org/10.1068/a44349

Krueger, A.O. 1974. The political economy of the rent-seeking society. The American Economic Review 64(3): 291-303.

Laband, D.N. and J.P. Sophocleus. 2018. Measuring rent-seeking. Public Choice 1-21. https://doi.org/10.1007/s11127-018-0566-9

Larrain, B.F. and P.O. Perello. 2020. Can mining countries take advantage of their mining rents? A question of abundance, concentration and institutions. Oxford Development Studies 48(2): 148-165. https://doi.org/10.1080/13600818.2020.1 732898

Lawrence, J. and U. Tar. 2013. The use of grounded theory technique as a practical tool for qualitative data collection and analysis. Electronic Journal of Business Research Methods 11(1): 29-40.

Liu, Z. and A. Salzberg. 2012. Developing low-carbon cities in China: Local governance, municipal finance, and land-use planning - the key underlying drivers. In Sustainable low-carbon city development in China, eds. A. Bauemler, E. Ijjasz-Vasquez and S. Mehndiratta, 97-128. Washington, DC: World Bank.

Lockard, A. and G. Tullock, eds. 2001. Efficient rent-seeking: Chronicle of an intellectual quagmire. Boston: Kluwer Academic Publishers.

Mann, M. 2017. New public management and the 'business' of policing organised crime in Australia. Criminology and Criminal Justice 17(4): 382-400. https://doi.org/10.1177/1748895816671384

Marlyana Azyyati Marzukhi, Dasimah Omar, O.L.H. Leh, Na'asah Nasrudin and Azfarnizam Jaafar. 2019. Enhancing one stop centre in the Malaysian planning system. E3S Web of Conferences 101: Article no. 01001. https://doi.org/10 .1051/e3sconf/201910101001

Martinez-Gouhier, C. and R. Petersen. 2018. Regulation of the alcohol beverage industry: A sunset report on the Texas alcoholic benerage commission. Texas: Texas Public Policy Foundation.

Morse, J.M. 2015. Critical analysis of strategies for determining rigour in qualitative inquiry. Qualitative Health Research 25(9): 1212-1222. https://doi.org/10 $.1177 / 1049732315588501$

Murray, C.K. 2012. Markets in political influence: Rent-seeking, networks and groups. MRPA paper no. 42070. https://mpra.ub.uni-muenchen.de/42070/1/MPRA_ paper_42070.pdf (accessed 15 April 2020). 
Natow, R.S. 2019. The use of triangulation in qualitative studies employing elite interviews. Qualitative Research 20(2): 160-173. https://doi.org/10.1177/ 1468794119830077

Noni Harianti Junaidi and Dani Salleh. 2016. Masalah-masalah dalam kelulusan merancang pembangunan perumahan. Malaysian Journal of Social Sciences and Humanities 1(2): 36-44.

North, C.M., W.H. Orman and C.R. Gwin. 2013. Religion, corruption and the rule of law. Journal of Money, Credit and Banking 45(5): 757-779. https://doi.org/10 $.1111 /$ jmcb. 12024

North, D.C. 1986. The new institutional economics. Journal of Institutional and Theoretical Economics 142(1): 230-237.

Nowell, L.S., J.M. Norris, D.E. White and N.J. Moules. 2017. Thematic analysis: Striving to meet the trustworthiness criteria. International Journal of Qualitative Methods 16(1): 1-13. https://doi.org/10.1177/1609406917733847

Pande, R. 2007. Understanding political corruption in low income countries. In Handbook of development economics, eds. T.P. Schultz and J.A. Strauss, vol. 4, 3155-3184. Amsterdam: Elsevier. https://doi.org/10.1016/S1573-4471(07)04050-8

Patnaik, S. 2015. Rent-seeking and public policy. CESifo DICE Report 13(3): 3-5. http://hdl.handle.net/10419/167217 (accessed 28 September 2019).

Patton, M.Q. 2002. Qualitative research and evaluation methods. Thousand Oaks, CA: Sage.

Pelzang, R. and A.M. Hutchinson. 2017. Establishing cultural integrity in qualitative research: Reflections from a cross-cultural study. International Journal of Qualitative Methods 17(1): 1-9. https://doi.org/10.1177/1609406917749702

Prior, M.T. 2018. Accomplishing "rapport" in qualitative research interviews: Emphatic moments in interaction. Applied Linguistic Review 9(4): 487-511. https://doi. org/10.1515/applirev-2017-0029

Quesada, M.G., F. Jiménez-Sánchez and M. Villoria. 2013. Building local integrity systems in Southern Europe: The case of urban local corruption in Spain. International Review of Administrative Science 79(4): 618-637. https://doi. org/10.1177/0020852313501125

Rogow, A.A. 1954. Relations between the labour government and industry. The Journal of Politics 16(1): 3-23. https://doi.org/10.2307/2126336

Roulston, K. and M. Choi. 2018. Qualitative interviews. In The SAGE handbook of qualitative data collection, ed. U. Flick, 233-245. London: Sage Publications Ltd. https://doi.org/10.4135/9781526416070.n15

Rowley, C.K. 2013. Rent-seeking versus directly unproductive profit-seeking activities. In The political economy of rent-seeking, eds. C.K. Rowley, R.D. Tollinson and G. Tullock, 15-25. New York: Springer Science+Business Media. https://doi.org/10.1007/978-1-4757-1963-5_2

Samanta, S.K. 2011. Corruption, religion and economic performance in OPEC countries: An analysis. International Journal of Economics, Management and Accounting 19(2): 87-208. 
Samuels, W.J. 1992. A critique of rent-seeking theory. In Essays on the economic role of government, Vol. 2: Applications, ed. W.J. Samuels, 111-128. London: Palgrave Macmillan. https://doi.org/10.1007/978-1-349-12377-3_6

Samuels, W.J. and N. Mercuro. 1986. Posner and the efficiency of the common law. International Review of Law and Economics 1(6): 31-45. https://doi.org/10 $.1016 / 0144-8188(86) 90046-3$

Saunders, B., J. Sim, T. Kingstone, S. Baker, J. Waterfield, B. Bartlam, H. Burroughs and C. Jinks. 2018. Saturation in qualitative research: Exploring its conceptualisation and operationalisation. Quality and Quantity 52(4): 1893-1907. https://doi.org/ 10.1007/s11135-017-0574-8

Saunders, M., P. Lewis and A. Thornhill. 2016. Research methods for business students. 7th ed. Harlow, UK: Pearson Education Limited.

Searle, G. 2016. Towards equitable intensification: Restricting developer gain and compensating planning cost. In Instruments of planning. Tensions and challenges for more equitable and sustainable cities, eds. R. Lechinsky and C. Legacy, 3950. New York: Routledge.

Silverman, D. 2014. Interpreting qualitative data. London: SAGE Publications Ltd.

Sundaresan, J. 2017. Who is corrupt and where lies corruption? Thinking with land use planning violations in Bangalore. In The illicit and illegal in regional and urban governance and development: Corrupt places, eds. F. Chiodelli, T. Hall and R. Hudson, 256-274. Abingdon: Routledge. https://doi.org/10.4324/ 9781315317663-15

Thompson, D.F. 1987. Political ethics and public office. Cambridge, MA: Harvard University Press.

Transparency International. 2013. Global corruption barometer. Berlin, Germany: Transparency International.

Tullock, G. 1967. The welfare costs of tariffs, monopolies, and theft. Western Economic Journal 5(3): 224-232. https://doi.org/10.1111/j.1465-7295.1967.tb01923.x

Tullock, G. 1980. Efficient rent-seeking. In Toward a theory of the rent-seeking society, eds. J.M. Buchanan, G. Tollison and G. Tullock, 97-112. College Station, TX: Texas A\&M University Press.

Vogt, C., J. Weimann and C.-L. Yang. 2002. Efficient rent-seeking in experiment. Public Choice 110: 67-78. https://doi.org/10.1023/A:1013051501754

World Bank. 2013. Doing business 2014. Washington, DC: The World Bank. http://www.transparency.org/gcb2013 (accessed 4 September 2019). 2015. Achieving a system of competitive cities in Malaysia. Main report. Washington, DC: The World Bank.

Yin, R.K. 2016. Qualitative research from start to finish. 2nd ed. New York: Guilford Press.

Zingales, L. 2014. A capitalism for the people: Recapturing the lost genius of American prosperity. New York: Basic Books. 